Check for updates

The BMJ

kabbasi@bmi.com Follow Kamran on Twitter@KamranAbbasi Cite this as: $B M / 2021 ; 372: n 239$ http://dx.doi.org/10.1136/bmj.n239 Published: 28 January 2021

\section{Why vaccinating staff and supporting self-isolating people are national emergencies}

\section{Kamran Abbasi executive editor}

Equity is complex and multifaceted. It requires many interventions that in small ways build a bigger success. It is deaf to bombast and magic bullets. Equity is easily discussed and championed but takes commitment to achieve. In the early days of the covid pandemic it was fashionable to champion people in lower socioeconomic groups, ethnic minorities, and frontline health professionals. Now all these groups feel wronged and to some extent abandoned.

Availability of vaccines has widened fault lines, globally and nationally. The political economy of covid-19 reinforces historical patterns of "resource extraction from poorer countries," influenced by racial discrimination, marginalisation, and colonialism. ${ }^{1}$ The world was found wanting on universal preparedness and solidarity. ${ }^{2}$ Failed political leadership has led to an uncoordinated and ineffective response. ${ }^{3}$ The truth remains elusive, ${ }^{4}$ and social media organisations are only now awakening to their responsibilities. ${ }^{5}$

After 100 ooo deaths, ${ }^{6}$ and the worst per capita performance of any major nation, the UK persists in neglecting key groups. Ethnic minorities are not identified in vaccine research and are not a priority for vaccination. This raises a question about the vaccine strategy: is age the main driver of risk? Or is it less important than income, occupation, household circumstances, or comorbidities-all factors that make ethnic minorities more vulnerable? Is the invisibility of ethnic minorities from vaccine priorities another example of structural racism? ${ }^{7}$

A pandemic that feeds on inequalities favours the rich. But none of us will get out of this unless we stop the spread of the virus. Where is the support for people unable to self-isolate because they are on low incomes and have to work or care for others? "Integrating equitable support services for those most at risk for covid-19 is a national emergency," warn Muge Cevik and colleagues. ${ }^{8}$ Solutions are available, from short term financial support to ongoing universal basic income, and backed by evidence. ${ }^{9}$ But adequate support for self-isolating people is missing and ignored. That can't be the case if we are serious about reducing transmission and deaths, even if it goes against political ideology.

Similarly, if we're serious, we must prioritise protection of health professionals. The new variant of SARS-CoV-2 may be more deadly, ${ }^{10}$ and it might affect vaccine dosing strategies. Moderna, for example, will trial a third dose of its vaccine because of concerns about a drop in immunogenicity, ${ }^{11}$ placing the UK's reliance on single doses and extending the dosing interval to 12 weeks under greater scrutiny. ${ }^{12}$ In these circumstances, and given high levels of staff absence, overwhelming pressure on covid and non-covid services, ${ }^{13}$ and falling morale and medicolegal worries, ${ }^{14-16}$ providing full vaccination to frontline health professionals must be an immediate priority and an unbreakable vow.

Isn't that better for patients? Do we need complex modelling to follow and implement the same simple logic as other nations? Or will the inequitable policies towards people on low incomes, minorities, and health professionals be added to a list of spectacular, deadly, but obvious government errors, of which failing to support self-isolating people remains a damaging example?

Bump JB, Baum F, Sakornsin M, Yates R, Hofman K. Political economy of covid-19: extractive, regressive, competitive. BMJ2021;372:n73. doi: 10.1136/bmj.n73 pmid: 33483317

2 Tomson G, Causevic S, Ottersen OP, etal. Solidarity and universal preparedness for health after covid-19. BM/2021;372:n59.pmid: 33483301 Tangcharoensathien V, Bassett MT, Meng Q, Mills A. Are overwhelmed health systems an inevitable consequence of covid-19? Experiences from China, Thailand, and New York State. BMJ2021;372:n83.pmid: 33483336

4 Oliver D. David Oliver: Covid shows the need for transparency in prioritising acute care. BMJ 2021;372.

5 Wardle C, Singerman E. Too little, too late: social media companies' failure to tackle vaccine misinformation poses a real threat. BMJ2021;372:n26. doi: 10.1136/bmj.n26 pmid: 33478950

6 Shepherd A. Covid-19: "We must learn the lessons of this dark death toll". BMJ 2021;372:n237. doi: 10.1136/bmj.n237 pmid: 33500256

Razai MS, Kankam HKN, Majeed A, Esmail A, Williams DR. Mitigating ethnic disparities in covid-19 and beyond. BMJ2021;372:m4921. doi: 10.1136/bmi.m4921 pmid: 33446485

8 Cevik M, Baral SD, Crozier A, Cassell JA. Support for self-isolation is critical in covid-19 response. BM/2021;372.

9 Patel SB, Kariel J. Universal basic income and covid-19 pandemic. BMJ 2021;372:n193. doi: 10.1136/bmj.n193 pmid: 33500257

10 lacobucci G. Covid-19: New UK variant may be linked to increased death rate, early data indicate. BM/2021;372:n230. doi: 10.1136/bmj.n230 pmid: 33500262

11 Tanne JH. Covid-19: Moderna plans booster doses to counter variants. BMJ 2021;372:n232. doi: 10.1136/bmj.n232 pmid: 33500251

12 Mahase E. Covid-19: Medical community split over vaccine interval policy as WHO recommends six weeks. BMJ2021;372:n226. doi: 10.1136/bmi.n226 pmid: 33495166

13 lacobucci $G$. How is the pandemic affecting non-covid services?BMJ 2021;372:n215. doi: 10.1136/bmi.n215 pmid: 33483334

14 Rimmer A. How can I boost team morale?BMJ 2021;372:n183. doi: 10.1136/bmj.n183 pmid: 33495154

15 Dyer C. Covid 19: How to feel safe working on the front line-your legal and ethical questions answered. BM/2021:372:n179. doi: 10.1136/bmj.n179 pmid: 33472849

16 Dacre J. Doctors must be protected as pressure on health service grows. BMJ Opinion. 16 Jan 2021. https://blogs.bmj.com/bmj/2021/01/16/janedacre-doctors-must-be-protected-as-pressure-on-health-service-grows.

This article is made freely available for use in accordance with BMJ's website terms and conditions for the duration of the covid-19 pandemic or until otherwise determined by BM]. You may use, download and print the article for any lawful, non-commercial purpose (including text and data mining) provided that all copyright notices and trade marks are retained. 